\title{
Determination of Field Capacity in a Florida Sandy Soil and Drainage Time at Different Depths
}

\author{
M ongi Zekri ${ }^{1}$ and \\ L awrence R. Parsons ${ }^{2}$
}

AdDitional INDEX words. capacitance probe, irrigation, neutron probe, soil water content

Summary. The development of improved equipment for measuring soil water content has created the need for a better understanding of soil water drainage and movement. Without this understanding, it is impossible to know if an observed decrease in soil water content at a particular depth is due to evapotranspiration and/ or continual drainage. This study was designed to determine the length of time for different soil depths of a F lorida $C$ andler fine sand to reach field capacity. A field site with no vegetation on it was saturated with water and covered with a plastic tarp to prevent evaporation. At 6- to 24-hour intervals, soil water content was measured gravimetrically in the top $15 \mathrm{~cm}$ ( 6 inches) and with the neutron probe from 30 to $150 \mathrm{~cm}$ (12 to 59 inches). The 15-cm depth reached field capacity after one day, but it took 4 days for the 30- to 150cm depths to reach field capacity because of rewetting by water draining form higher horizons. The time required for drainage to stop must be considered when evaluating changes in soil water status at a particular depth. This is important for distinguishing between plant water uptake and drainage for different soil layers.Soil water characteristic curves of undisturbed soil samples, bulk

Florida Agricultural Experiment Station journal series no. R-06442. The cost of publishing this paper was defrayed in part by the payment of page charges. U nder postal regulations, this paper therefore must be hereby marked advertisement solely to indicate this fact.

${ }^{1} \mathrm{U}$ niversity of Florida, $\mathrm{H}$ endry $\mathrm{C}$ ounty Extension $\mathrm{O}$ fice, P.O. Box 68, LaBelle, FL 33975

${ }^{2} \mathrm{U}$ niversity of Florida, $C$ itrus R esearch and Education Center, 700 Experiment Station Road, L akeAlfred, FL 33850 . 
density, porosity, and field capacity in situ were also determined for this soil. Field capacity values found in situ were compared to those found using the pressure plate technique. Laboratory values were higher than field values because the laboratory data were closer to hydrostatic conditions than the field data and the degree of saturation provided during wetting of the cores was higher in the laboratory. Water was not readily retained in C andler fine sand because the soil was very porous, infiltration rates were high, drainage was rapid, and water storage capacity was limited. U sing field measurements, field capacity values of soil at different depths ranged from $4.8 \%$ to $6.2 \%$ volume for $C$ andler fine sand. These are considered to be low values when compared to other types of soil.

$\mathrm{S}$ oil water status has a major effect on plant growth and productivity. Various instruments have been used to determine soil water content or tension, but many of these give only snapshot views of soil water at a particular time. N ewer devices are now available which measure changes in soil water status at different depths on a near-continuous basis [e.g., capacitance probe, EnviroSCAN; Sentek Environmental Innovations, Kent Town, South Australia; and time domain reflectometry (TD R)] (Paltineanu and Starr, 1997). These devices have shown decreases in soil water over timedue to plant evapotranspiration (ET) and/ or drainage. Without knowledge of duration of soil drainage, it is difficult to determine if changes in soil water content are due to plant ET or drainage. This study was designed to determinefield capacity in a deep Florida ridge sand and the length of time required for water to drain through the soil.

The study of water uptake and retention by soils is of significant importance. Curvesshowing the relation between water content and soil water tension have been intensively used to understand the physical characteristics of soils. The desorption curve, known as the soil water release curve, is commonly used (H illel, 1980) becausesoil is exposed most of the time to drying conditions due to water extraction by plants. Field capacity is an important concept which is defined as the water content of an initially wetted soil after downward movement of water has materially decreased (H illel, 1980). Field capacity determinations in place or in situ are generally superior to those in the laboratory because it is difficult to obtain samples and transport them to the laboratory without disturbing them to some extent. Furthermore, there is no laboratory system yet devised that is capable of duplicating soil water dynamics in the field (H illel, 1982).

Candler fine sand (hyperthermic, uncoated, Typic Q uartzipsamments) is a common soil for growing citrusin the central Florida ridge. Significant differences in physical characteristics such as water holding capacities of $C$ andler fine sands have been found among Florida counties (C arlisle et al., 1985; $\mathrm{H}$ ammond et al., 1967; Stewart et al., 1963). Differences within the same county have also been found, particularly in the top $10 \mathrm{~cm}$ (4 inches) of soil (Carlisle et al., 1985). Because small differences in field capacity in sands can make large difference in available water, a need for determining soil water characteristic curvesand field capacity values for every location is important.

Florida ridge sands are particularly low in water holding capacity, and it has been stated that drainage generally ceases after $24 \mathrm{~h}$ (O breza et al., 1997). H owever, recent improvements in soil water measurement techniques such as systems that measure the soil dielectric constants allow us to monitor soil water status at different depths almost continuously (Paltineanu and Starr, 1997). With these newer nearcontinuous measuring devices, it is sometimes difficult to determine if changes in soil water status are due to continual drainage, ET or a combination of both factors. $\mathrm{H}$ ence, it has now become more important to determine the time required for drainage to substantially decrease at different depths in sandy soils.

The objective of this study was to determinethetime required for drainage within different soil depths to becomenegligible. A nother objective was to determine soil water content values at different soil pressure heads during desorption from undisturbed soil cores, and to estimatefield capacity in situ for different depths of aC andler finesand. For extension and research personnel, it is important to understand these concepts to better evaluate drainage and plant water uptake.

\section{Materials and methods}

A neutron probe (model 503 D R; CPN Corp., Pacheco, Calif.) was calibrated in the field by the gravimetric method. The calibration was conducted by daily augering and collecting undisturbed soil samples from the depths at which neutron probe count ratio readings were taken. $V$ olumetric soil water content values were determined after oven drying known volumes of the soil samples to a constant weight at $105^{\circ} \mathrm{C}\left(221^{\circ} \mathrm{F}\right)$. The bestfitting curve and equation relating count ratio and water content were computed. Three aluminum access tubes were installed in the soil of a citrus orchard near D avenport, Fla., for neutron probe measurements. The soil was $C$ andler fine sand (Entisol, hyperthermic, uncoated, Typic Q uartzipsamments), which was typical of the ridge area of central Florida. Thesite chosen was $>10 \mathrm{~m}$ ( $33 \mathrm{ft}$ ) from citrus trees and other vegetation to avoid water absorption by roots. A large portion of soil was wetted and saturated beyond the depth of interest by irrigating overnight with one sprinkler discharging $125 \mathrm{~L} \cdot \mathrm{h}^{-1}$ (33 gal/ h). The area was then covered with a plastic tarp to prevent evaporation. Soil water content wasmonitored gravimetrically in the top $15 \mathrm{~cm}$ ( 6 inches) and by the neutron scattering method from 30 to $150 \mathrm{~cm}$ (12 to 59 inches) deep. At 6- to 24-h intervals, measurements of soil water content were taken which provided information on the dynamic pattern of internal drainage and allowed evaluation of whether any single value of soil water at any particular time could be designated as field capacity.

Water uptake and release by the soil were measured by the pressure plate technique (Richards and Fireman, 1943). Six replicate soil samples were collected at appropriate depths with a soil sampler equipped with 5.4$\mathrm{cm}$ (2.1-inch)-diameter and 6.0-cm (2.4-inch)-high brasscores, which provided soil cores of substantially undisturbed structure. Samples were collected several feet apart within the neutron probesite at depths of 0 to 15 , $30,60,90,120$, and $150 \mathrm{~cm}$. The bottom surface of the soil sample was covered with cheesecloth held in place with a rubber band to retain the soil, and water was added to the top of the cylinders until the cores were nearly 
T able 1. Volumetric soil water content (\%) of a $\mathrm{C}$ andler fine sand at different soil suctions.

\begin{tabular}{lcccc}
\hline $\begin{array}{l}\text { Depth } \\
\text { [cm (inch)] }\end{array}$ & \multicolumn{4}{c}{ Suction kPa (bar) } \\
\cline { 2 - 5 } $\mathbf{1 0 ( 0 . 1 )}$ & $\mathbf{2 0 ( 0 . 2 )}$ & $\mathbf{3 0 ( 0 . 3 )}$ & $\mathbf{1 0 0 ( 1 . 0 )}$ \\
\hline $0-15(0-6)$ & 7.52 & 7.06 & 6.48 & 6.17 \\
$30(12)$ & 6.83 & 6.04 & 5.51 & 4.78 \\
$60(24)$ & 5.78 & 5.07 & 4.55 & 4.13 \\
$90(35)$ & 5.26 & 4.76 & 4.26 & 3.32 \\
$120(47)$ & 5.52 & 4.90 & 4.49 & 3.44 \\
$150(59)$ & 6.02 & 5.46 & 5.21 & 3.36 \\
\hline
\end{tabular}

T able 2. Bulk density, porosity, and field capacity of a $\mathrm{C}$ andler fine sand for different depths.

\begin{tabular}{|c|c|c|c|c|}
\hline $\begin{array}{l}\text { Depth } \\
\text { [cm (inch)] }\end{array}$ & $\begin{array}{c}\text { Bulk } \\
\text { density } \\
\left(\mathrm{g}^{\prime} \mathrm{cm}^{-3}\right)\end{array}$ & $\begin{array}{c}\text { Porosity } \\
(\%)\end{array}$ & $\begin{array}{l}F C^{x} \\
(\%)\end{array}$ & $\begin{array}{l}\text { Time to } \\
\text { reach } \\
\text { FC } \\
\text { (d) }\end{array}$ \\
\hline $\begin{array}{l}0-15(0-6) \\
30(12) \\
60(24) \\
90(35) \\
120(47) \\
150(59)\end{array}$ & $\begin{array}{l}1.40 \\
1.57 \\
1.54 \\
1.50 \\
1.51 \\
1.52\end{array}$ & $\begin{array}{l}47.17 \\
40.75 \\
41.89 \\
43.40 \\
43.02 \\
42.64\end{array}$ & $\begin{array}{l}6.2 \\
5.7 \\
5.1 \\
4.8 \\
4.9 \\
5.5\end{array}$ & $\begin{array}{l}1 \\
4 \\
4 \\
4 \\
4 \\
4\end{array}$ \\
\hline
\end{tabular}

${ }^{2} 1.0 \mathrm{~g} \cdot \mathrm{cm}^{-3}=62.43 \mathrm{lb} / \mathrm{ft}^{3}$.

YPorosity values were calculated using $2.65 \mathrm{~g} \cdot \mathrm{cm}^{-3}$ as a mean particle density.

${ }^{\mathrm{X} F C}=$ field capacity.

saturated. The porous ceramic pressure plate was saturated with water under vacuum. When soil sampleswere set on the porousplate in the extractor (or chamber) and pressure was applied, water was extracted from the soil. The water passed into a burette through a delivery tube connected to the underside of the porous plate. The equilibrium and amount of water can then be conveniently obtained without the disturbance caused by successiveweighing. Precaution wastaken to prevent evaporation from the burette by using a small amount of mineral oil in it. The pressures applied in the chamber were $10,20,30$, and $100 \mathrm{kPa}$ $(0.1,0.2,0.3$, and 1.0 bar). When equilibrium at the last pressure (100 $\mathrm{kPa}$ ) was reached, soil water content was determined by drying to constant weight at $105^{\circ} \mathrm{C}\left(221^{\circ} \mathrm{F}\right)$.

\section{Results and discussion}

Soil water content decreased with increasing soil suction (Table 1 ). The top 0 to $15 \mathrm{~cm}$ of soil had the highest water-holding capacity. Water-holding capacity of the soil decreased with depth from the soil surface to a depth of $90 \mathrm{~cm}$ (35 inches) due mainly to a decrease in organic matter concentration. Below the $90-\mathrm{cm}$ depth, water holding capacity increased with depth due to a slight increase in clay concentration. The top 0 to $15 \mathrm{~cm}$ of soil had the lowest bulk density and the highest porosity (Table 2) due also to higher organic matter content and frequent tillage.

Thewater content of thesix depths in relation to time after wetting is plotted in Figs. 1 and 2. During the first few hours after wetting, most of the water had drained at a relatively rapid rate, illustrated by thesteep slopes of the soil water depletion curves (Fig. 1). O ne to two days after wetting, the rate of water loss due to drainage dropped to $<1 / 10$ of the initial rate, and after 4 to $5 \mathrm{~d}$ the rate dropped to $1 / 100$ of the initial rate. $O$ ne day after wetting, the 0 - to 15 -cm curve started to level off, but it took $4 \mathrm{~d}$ for the $150-\mathrm{cm}$ curve to start flattening (Fig. 1) because of rewetting by water draining from the upper horizons. The 30-, 60-, 90-, and $120-\mathrm{cm}$ curves followed the same pattern. The 30-cm curve was relatively higher than theothers dueto higher organic matter concentration. Field capacity at $150 \mathrm{~cm}$ was as high as that at $30 \mathrm{~cm}$ because of the relatively higher clay concentration.

Furr (1945) assumed that in sandy soilsthat were free of a hard- pan, rapid drainage after wetting had to becompleted in 2 to $4 \mathrm{~d}$ and that the water content of samples taken at the end of this period represented the approximate field capacity. Kramer (1969) suggested that drainage of gravitational water became very slow 1 to $3 \mathrm{~d}$ after soil had been thoroughly wetted by rain or irrigation. Veihmeyer and $\mathrm{H}$ endrickson (1949) stated that field capacity was in the region where the soil water-release curve became almost horizontal. Stewart et al. (1963) arbitrarily set field capacity for sandytextured soils at $10.1 \mathrm{kPa}(0.10$ atmosphere) tension and Schwab et al. (1966) defined field capacity in sands at $10.0 \mathrm{kPatension}$. Recently, with the development of more precise experimental techniques in the study of un-

Fig. 1. Volumetric water content for the different depths in relation to time after wetting.

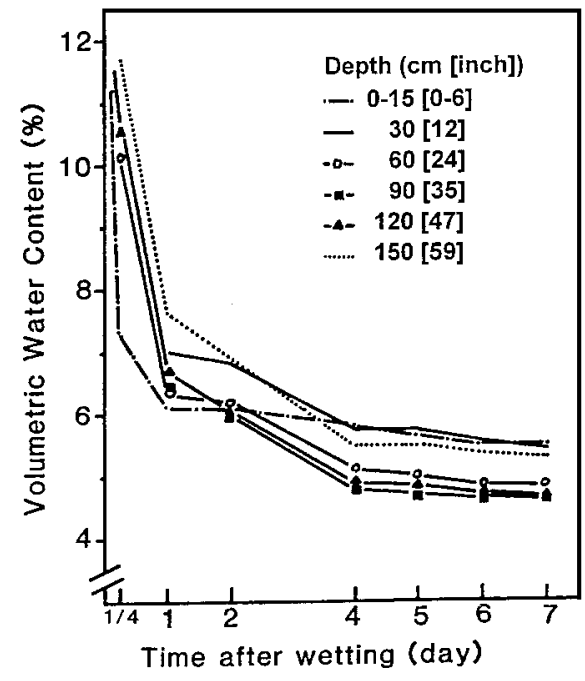

Fig. 2. Volumetric water content of the top $150 \mathrm{~cm}$ (59 inches) of soil in relation to time after wetting.

Volumetric Water Content (\%)

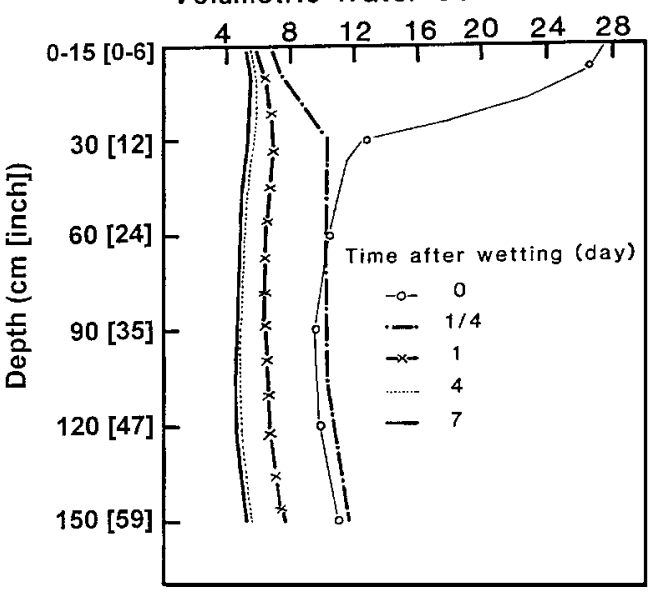

Hortlechnology • A pril-J une 1999 9(2) 
saturated flow processes, the field capacity concept, as defined above, has been recognized as arbitrary and not an intrinsic physical property independent of the way it is measured (H illel, 1982). Although the rate of water redistribution in the soil profile decreases constantly, in the absence of a water table the process continues for very long periods (H illel, 1982).

$\mathrm{O}$ ur field capacity values were selected based mainly on Veihmeyer and $\mathrm{H}$ endrickson's criteria. These values arelocated on the portion of the curves corresponding to 1 day for the top 15$\mathrm{cm}$ depth and $4 \mathrm{~d}$ for the other depths after wetting (Table 2, Fig. 1). The amount of water that was retained at $10 \mathrm{kPa}$ tension for $\mathrm{C}$ andler fine sand washigher than theamount of water at field capacity determined under field conditions. Field capacity values determined under field conditions were close to water content valuesat $20 \mathrm{kPa}$ suction. Thesedataagreewith Richards and O gata's results (1956), which showed higher water retention by cores in the laboratory compared with field determination. This was attributed to the higher degree of saturation provided during wetting of cores in the laboratory. From apractical stand point, bringing water content above field capacity by irrigation would be inefficient because this water will be lost by percolation and/ or deep drainage. $\mathrm{N}$ evertheless, because of the small amount of water held by this soil, it is also important to prevent the water content from falling low enough for plant water stress to occur.

\section{Conclusions}

Candler fine sand holds a relatively small amount of water and drains easily. Although the top $15 \mathrm{~cm}$ reaches field capacity in $\approx 1 \mathrm{~d}$, it takes $4 \mathrm{~d}$ for depths to $150 \mathrm{~cm}$ to materially stop draining. When monitoring plant water uptake from different soil depths, it is important to know how those particular depths will continue to lose water by drainage.

\section{Literature cited}

Carlisle, V.W., M .E. Collins, F. Sodek, III, and L.C. H ammond. 1985. Characterization data for selected Florida soils. U niv. Fla., Gainesville, Soil Sci. Res. Rpt. 85-1.

Furr, J.R. 1945. Soil water factors of importance in citrus and avocado grove management. Proc. Fla. StateH ort. Soc. 58:1625.

H ammond, L.C., H.W. L undy, and G.U . Saxena. 1967. Influence of underground asphalt barriers on water retention and movement in Lakeland fine sand. Proc. Soil Crop Sci. Soc. Fla. 27:11-19.

H illel, D . 1980. Fundamentals of soil physics. Academic Press, N ew York.

H illel, D . 1982. I ntroduction to soil physics. A cademic Press, N ew York.

Kramer, P.J. 1969. Plant and soil water relationships: A modern synthesis. M cG raw-H ill, N ew York.

Obreza, T.A., D.J. Pitts, L.R. Parsons, T.A. Wheaton, and K.T. M organ. 1997. Soil water-holding characteristic affects citrus irrigation scheduling strategy. Proc. Fla. State H ort. Soc. 110:36-39.

Paltineanu, I.C. and J.L. Starr. 1997. Realtime soil water dynamicsusing multisensor capacitanceprobes: L aboratory calibration. Soil Sci. Soc. Amer. J. 61:1576-1585.

Richards, L.A. and M. Fireman. 1943. Pressure plate apparatus for measuring water sorption and transmission by soils. Soil Sci. 56:395-400.

Richards, L.A. and G. O gata. 1956. M aterials for retainer plates and their use for retentivity measurements. Proc. Soil Sci. Soc. Amer. 20:303-306.

Stewart, E.H., D.P. Powell, and L.C. $\mathrm{H}$ ammond. 1963. Water characteristics of somerepresentativesoilsof Florida. U SD AARS 41-63.

Schwab, G.O., R.K. Frevent, T.W. Edminster, and K.K. Barnes. 1966. Soil and water conservation engineering. Wiley, New York.

Veihmeyer, F.J. and A.H. H endrickson. 1949. M ethods of measuring field capacity and permanent wilting percentage of soils. Soil Sci. 68:75-94. 